JUN 261960

ANL-79-59
Stem $42 \%-T-4$

E1.28: RNL-79-59

ANL-79-59

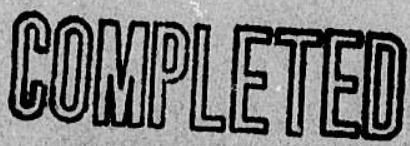

ORIGINAL

\title{
A PRELIMINARY ESTIMATE OF THE MANUFACTURING COST FOR LITHIUM/METAL SULFIDE CELLS FOR STATIONARY AND MOBILE APPLICATIONS
}

by

A. A. Chilenskas, J. C. Schaefer,

W. L. Towie, and D. L. Barney


ARGONNE NATIONAL LABORATORY, ARGONNE, ILLINOIS

Prepared for the U. S. DEPARTMENT OF ENERGY under Contract W-31-109-Eng-38 
The facilities of Argonne National Laboratory are owned by the United States Government. Under the terms of a contract (W-31-109-Eng-38) among the U. S. Department of Energy, Argonne Universities Association and The University of Chicago, the University employs the staff and operates the Laboratory in accordance with policies and programs formulated, approved and reviewed by the Association.

\section{MEMBERS OF ARGONNE UNIVERSITIES ASSOCIATION}

The University of Arizona

Carnegie-Mellon University

Case Western Reserve University

The University of Chicago

University of Cincinnati

Illinois Institute of Technology

University of Illinois

Indiana University

The University of Iowa

Iowa State University
The University of Kansas

Kansas State University

Loyola University of Chicago

Marquette University

The University of Michigan

Michigan State University

University of Minnesota

University of Missouri

Northwestern University

University of Notre Dame
The Ohio State University

Ohio University

The Pennsylvania State University

Purdue University

Saint Louis University

Southern Illinois University

The University of Texas at Austin

Washington University

Wayne State University

The University of Wisconsin-Madison

\section{NOTICE}

This report was prepared as an account of work sponsored by an agency of the United States Government. Neither the United States Government or any agency thereof, nor any of their employees, make any warranty, express or implied, or assume any legal liability or responsibility for the accuracy, completeness, or usefulness of any information, apparatus, product, or process disclosed, or represent that its use would not infringe privately owned rights. Reference herein to any specific commercial product, process, or service by trade name, mark, manufacturer, or otherwise, does not necessarily constitute or imply its endorsement, recommendation, or favoring by the United States Government or any agency thereof. The views and opinions of authors expressed herein do not necessarily state or reflect those of the United States Government or any agency thereof.

Printed in the United States of America

Available from

National Technical Information Service

U. S. Department of Commerce

5285 Port Royal Road

Springfield, VA 22161

NTIS price codes

Printed copy: $\mathrm{A} 03$

Microfiche copy: A01 
Distribution Category:

Energy Storage--Electrochemical-

Advanced Batteries (UC-94cb)

ANL-79-59

\begin{abstract}
ARGONNE NATIONAL LABORATORY
9700 South Cass Avenue

Argonne, Illinols 60439
\end{abstract}

\title{
A PRELIMINARY ESTIMATE OF THE MANUFACTURING COST FOR LITHIUM/METAL SULFIDE CELLS FOR STATIONARY AND MOBILE APPLICATIONS
}

by

A. A. Chilenskas, J. C. Schaefex, * W. L. Towle, ** and D. L. Barney

Chemical Engineering Division

January 1980

* Industrial Particlpant from ESB/Ray-0-Vac Corp. **Private Consultant to ANL 

ABSTRACT . . . . . . . . . . . . . . . . . . . . 1 1/A6

I. INTRODUCTION. ................... 1 ...A6

II. CONSTRUCTION OF L1-A1/FeS $\mathrm{FELLS}_{\mathrm{x}}$. . . . . . . . . . . 2 1/A7

III. COST ANALYSIS . . . . . . . . . . . . . . 4 1/A9

A. Materials Costs ................ 4 1/A9

B. Costs for Plant, Production Equ1pment and Labor . . . 9 1/A14

C. Cell Manufacturing Cost ............. 10 1/B1

IV. A COMPARISON BETWEEN ANL AND ARTHUR D. LITTLE MANUFACTURING COST METHODOLOGY . . . . . . . . . . . . 14 1/B6

V. LITHIUM RESOURCES AND REQUIREMENTS . . . . . . . . . . 15 1/B7

A. Reserves/Resources Lithlum . . . . . . . . . 15 1/B7

B. Lithium Requirements .............. 16 1/B8

vI. CONCLUDING REMARKS . . . . . . . . . . . . . 17 1/B9 
No.

1.

2. Lithium-Aluminum/Iron Su Cost Estimates for SES and EV Cells. . . . . . .

LIST OF TABLES

No.

1.

2.

3.

4.

5.

6.

7.

8.

9. Cost. Calculation for EV Cell Produced in

10.

11.

12.

13.

Title

Page

3

12

Title

Page

The Minimum Weights of Reactant Materials for a Li-Al/FeS Cell

Weights of Components in LI/FeS $\mathrm{Cells}_{\mathrm{x}}$. . . . . . 5

Electrolyte Requirements for LI/FeS Cells . . . . . 6

Current Collector Welght for L1/FeSx Cells . . . . . 6

A Range of Material Costs for LI/FeS Cells . . . . 7

Most Expensive Materials In a L1/FeS Cell . . . . . 8

Equipment and Labor Costs for SES Cell . . . . . . 9

Scaling Factors for SES and EV Cells . . . . . . . 10

a $1.15 \times 10^{6} \mathrm{kW-hr} / \mathrm{yr}$ Plant. . . . . . . . . . 11

Cell Manufacturing Cost Summary. . . . . . . . . 13

The SES Cell Manufacturing Costs According to Two

Costing Methodologies . . . . . . . . . . . 15

IdentIfled World LithIum Resources . . . . . . . 16

Projected Lithium Requirements for the U.S.A. . . .

17 
A PRELIMINARY ESTIMATE OF THE

MANUFACTUR ING COST FOR

LITHIUM/METAL SULFIDE CELLS FOR

STATIONARY AND MOBILE APFLICATIONS

by

A. A. Chilenskas, J. C. Schaefer, W. L. Towle, and D. L. Barney

ABSTRACT

A preliminary est lmate has been made of the manufacturing cost for lithium/Iron sulfide cells for stationary energy-storage and electricvehicle applications. This preliminary cost analysis indicated that the manufacturing cost (in 1979 dollars) is $\$ 24$ to $41 / \mathrm{kW}$-hr for stationary energy-storage cells and $\$ 31$ to $55 / \mathrm{kW}-\mathrm{hr}$ for electric-vehicle cells. The materials cost was found to contribute between 52 and $65 \%$ of this manufacturIng cost. The most expensive materials and components were 11thium (metal and compounds), $\$ 4.61$ to $\$ 14.26 / \mathrm{kW}-\mathrm{hr}$; BN felt, $\$ 4.00$ to $8.50 / \mathrm{kW}-\mathrm{hr}$; feedthrough components, $\$ 2.40 / \mathrm{kW}-\mathrm{hr}$; positive current collectors, $\$ 1.48$ to $2.20 /$ $\mathrm{kW}-\mathrm{hr}$; and aluminum, $\$ 1.43$ to $1.66 / \mathrm{kW}-\mathrm{hr}$.

The projected lithium requirements was determined for :1se in lithium/ iron sulfide batterles and conventional uses to the year 2006. The results showed that the lithlum requirements were about 275,000 short tons by 2006 , which is equivalent to about $51 \%$ of presently known U.S. resources. Of this amount, about $33 \%$ would be used in battery production and $67 \%$ consumed in conventional uses. It is expected that the lithfum used in battery production would be recycled.

\section{INTRODUCTION}

In a previous report (ANL-;6-12), 1 we estimated the manufacturing cost* based upon an estimate of the cost for cell materlals, plant construction, operating equipment, and labor of a $\mathrm{Li} / \mathrm{FeS}$ cell for a stationary energystorage (SES) battery for load-leveling applications. The present study updates this estimate and also provides an estimate of the manufacturing cost for electric-vehfcle (EV) $\mathrm{Li} / \mathrm{FeS}$ cells. These costs were profected for a second-generation manufacturing plant with a high production volume (1.15 $\mathrm{x}$ $10^{6} \mathrm{~kW}-\mathrm{hr} / \mathrm{yr}$ ).

Since the cost study of 1976, we have gained experience in the fabricatIon and operacton of EV cells and, therefore, can be more certain of our estinate of the cell composition. Furthermore, experience with cell fabrication Indicates that this system is amenable to mass production. However, because the $\mathrm{Li} / \mathrm{FeS}_{\mathrm{x}}$ battery is stiil in the research and development stage, there remains uncertainty in our estimates of the costs for materials and plant equipment. Consequently, the results reported here are preliminary

*A11 costs in this report are given in 1979 dollars unless otherwise indicated. 
and will require refinement at the pilot-manufacturing and full manufactur-

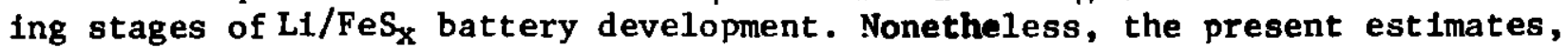
besides giving some indication of the ultimate manufacturing cost for the cell, point out cell components or materials that will be expensive so that future R\&D can be concerned with lowering the cost or finding means of eliminating high cost materlals or components.

\section{CONSTRUCTION OF $\mathrm{LI}-\mathrm{Al} / \mathrm{FeS}_{\mathrm{x}}$ CELLS}

The battery cells under development ${ }^{2}$ at Argonne Nationd1 Laboratory (ANL) have negative electrodes of IIthium-aluminum alloy, positive electrodes of metal sulfide, and an electrolyte of molten LiCl-KCl eutectic. Because the melting point of the electrolyte is $352^{\circ} \mathrm{C}$, the battery must be operated at temperatures above $400^{\circ} \mathrm{C}$. The cells have a prismatic configuration with vertically oriented electrodes (see Fig. 1). The negative and positive electrodes are separated by a porous materlal, such as boron nitride (BN) felt, which provides electrical Insulation between the electrodes and permits the migration of 11thium lons through the electrolyte. Two types of 1ron su1fides--FeS and $\mathrm{FeS}_{2}-$ are being used as the active materlal in most positive electrodes. The overall reactions for cells having FeS or $\mathrm{FeS}_{2}$ in the positive electrode are as follows:

$$
\begin{aligned}
& 2 \mathrm{LiAl}+\mathrm{FeS} \stackrel{2 \mathrm{e}-}{\longrightarrow} \mathrm{LI}_{2} \mathrm{~S}+\mathrm{Fe}+2 \mathrm{Al} \\
& 4 \mathrm{LiAl}+\mathrm{FeS}_{2} \stackrel{4 \mathrm{e}-}{\longrightarrow} 2 \mathrm{LI}_{2} \mathrm{~S}+\mathrm{Fe}+4 \mathrm{Al}
\end{aligned}
$$

The theoretical specific energies are about $460 \mathrm{~W}-\mathrm{hr} / \mathrm{kg}$ for reaction (1) and $650 \mathrm{~W}-\mathrm{hr} / \mathrm{kg}$ for reaction (2). Voltage v8. capactty curves show a single voltage plateau at $1.33 \mathrm{~V}$ (open circult) for reaction (1) and two plateaus of equal capacity at 1.76 and $1.33 \mathrm{~V}$ (open circuit), respectively, for reaction (2).

The 11thium/iron sulfide cell can be assembled in a charged or uncharged state. To assemble a $\mathrm{LI}-\mathrm{Al} / \mathrm{FeS}$ or $\mathrm{FeS}_{2}$ cell in the charged state, the negative electrodes are liormally pressed from LI-Al powder (usually 4650 at. \% 11thium), which may or may not be nixed with some of the LICI-KCl electrolyte powder. The positive electrodes are formed similarly by pressing FeS or $\mathrm{FeS}_{2}$ powder with or without added electrolyte powder. In the case of the uncharged cell, the positive electrode plaque is pressed from a mixture of $\mathrm{LI}_{2} \mathrm{~S}$ and iron powder in the appropriate proportions; the negative elec* trode in this case is an aluminum structure which is converted to the L1-A1 alloy electrochemically when the cell is charged.

The first developmental ( $40 \mathrm{~kW}-\mathrm{hr}$ ) Li-Al/Fes battery for EV applications has recently been fabricated by Eagle-Picher Industries under a contract from ANL. The cells built for this battery have a multiplate design (three Fes15 wt \% $\mathrm{Cu}_{2} \mathrm{~S}$ positive electrodes and four L1-A1 negative electrodes), dimensions of approximately $18.7 \times 19.7 \times 4.1 \mathrm{~cm}$, weight of about $3.8 \mathrm{~kg}$, theoretical capacities of $400 \mathrm{~A}-\mathrm{hr}$, and average discharge voltages of approximately $1.2 \mathrm{~V}$ at the $4-\mathrm{hr}$ rate. 


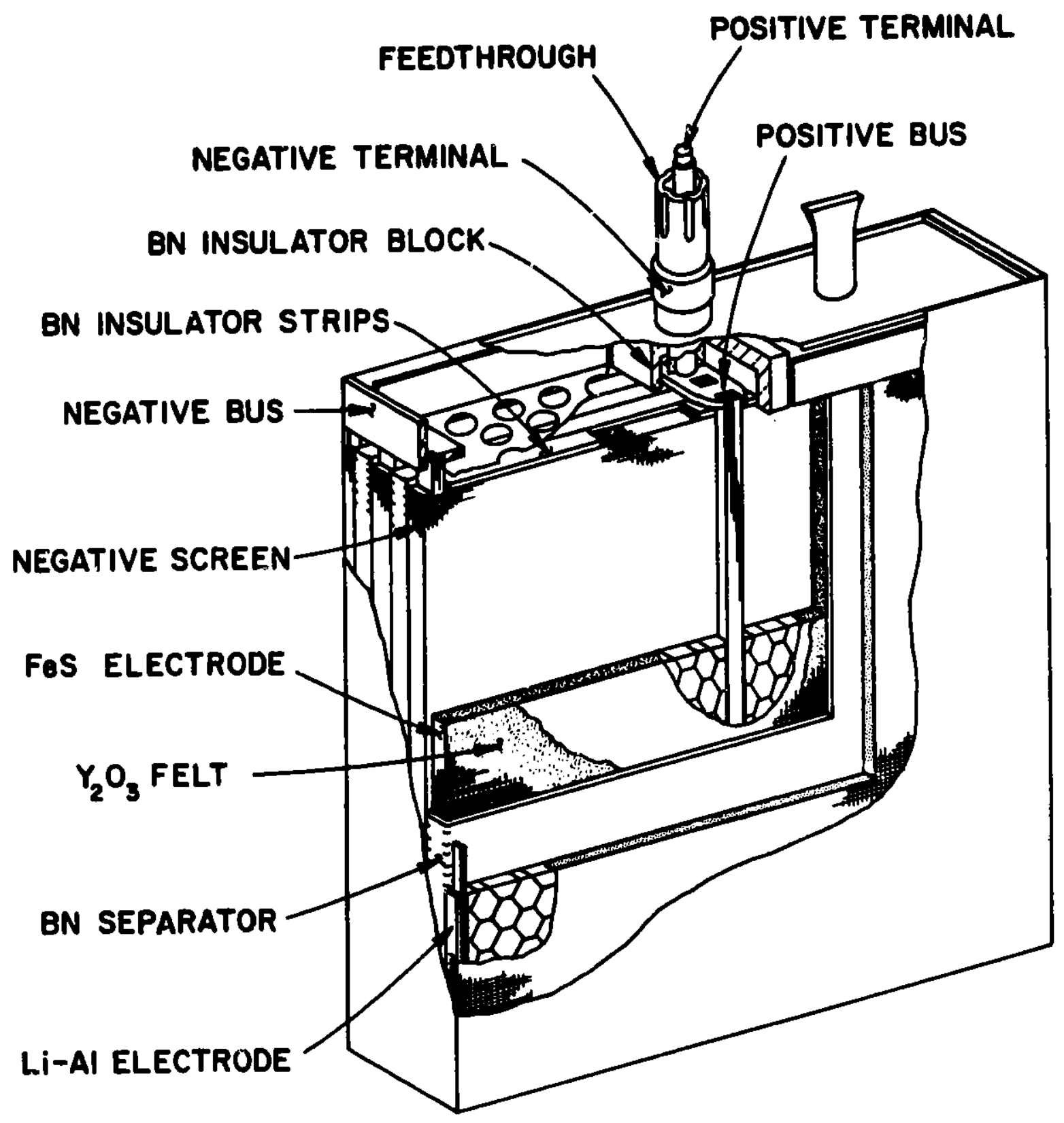

Fig. 1. Lithium-Aluminum/Iron Sulfide Cell

Very few SES cells have been tested. For the cost study of 1976, the cell design chosen consisted of L1-Al negative electrodes and FeS-23 wt \% $\mathrm{Cu}_{2} \mathrm{~S}$ positive electrodes and had dinensions of $31.1 \times 31.5 \times 2.5 \mathrm{~cm}$ and a welght of about $6.2 \mathrm{~kg}$. The theoretical cell capacity and average cell voltage were $1000 \mathrm{~A}-\mathrm{hr}$ and $1.15 \mathrm{~V}$, respectively. A further description of this design can be found in ANL-76-12, pp. 7-8. 
III. COST ANALYSIS

The cost contributions made to the manufacturing cost by the cell materlals, plant and production equipment, and labor are discussed below.

\section{A. Material Costs}

The materlals costs for the FeS and $\mathrm{FeS}_{2}$ cells were estimated by dete: mining the welght of the material or materials required for each cell compunent and then the expected cost for that materlal in mass production. The minjmum weight of reactant materials for a LI-Al/FeS cell assembled in the uncharged and charged states is given in Table 1 . These values are theoretical; In a practical cell, additional reactant material is necessary due to incomplete reactions and voltage drops.

Table 1. The Minimum Welghts of Reactant Materials for a LI-Al/FeS Cell

\begin{tabular}{cc}
\hline Materlals & Weight $^{\mathrm{a}}, 1 \mathrm{~b} / \mathrm{kW}-\mathrm{hr}$ \\
\hline Uncharged Cel1 $^{\mathrm{b}}$ & \\
$\mathrm{LI}_{2} \mathrm{~S}$ & 1.41 \\
$\mathrm{Fe}^{\mathrm{Al}}$ & 1.71 \\
& 1.65 \\
Charged Cel1 $^{\mathrm{C}}$ & \\
L1 Metal & 0.425 \\
FeS & 2.69 \\
A1 & 1.65 \\
\hline
\end{tabular}

\footnotetext{
${ }^{a}$ Based on $100 \%$ ut1lization of reagents at a voltage of $1.33 \mathrm{~V}$.

$b_{\text {The reaction }}$ is $\mathrm{LI}_{2} \mathrm{~S}+2 \mathrm{Al}+\mathrm{Fe} \rightarrow 2 \mathrm{LIAI}+\mathrm{FeS}$.

C The reaction $1 \mathrm{~s} 2 \mathrm{LIAl}+\mathrm{FeS} \rightarrow 2 \mathrm{Al}+\mathrm{LI}_{2} \mathrm{~S}+\mathrm{Fe}$.
}

To calculate the material cost for a practical cell, we derfved a reference cell design for EV applications based upon recently constructed ANL cells and the multiplate cells fabricated by Eagle-Plcher for the Mark IA battery. The reference EV cell consists of three positive electrodes and four negative electrodes and has dimensions of $18.1 \times 19.4 \times 3.13 \mathrm{~cm}$. The positive electrode has a theoretical capacity of $416 \mathrm{~A}-\mathrm{hr}$ and contains 50 vol $\%$ Iron sulfide and 50 vol \% LICl-KCl in dimenstons of $17.5 \times 17.5 \times 0.3 \mathrm{~cm}$. The negative electrode has a theoretical capacity of $458 \mathrm{~A}-\mathrm{hr}$ and contains 70 vol \% LI-Al and 30 vol \% electrolyte in dimensions of $17.5 \times 17.5 \times$ $0.5 \mathrm{~cm}$. The separator consists of 10 vol \% BN felt $\left(0.098-\mathrm{cm}\right.$ th $1 \mathrm{ck} ; 0.16-\mathrm{m}^{2}$ area). The rated capacity for this cell is $333 \mathrm{~A}-\mathrm{hr}$ at a discharge current density of $50 \mathrm{~mA} / \mathrm{cm}^{2}$. The design chosen for the SES reference cell was essentlally the same as that used for ANL-76-12 except that the separator material was changed from $\mathrm{BN}$ felt to $\mathrm{MgO}$ powder $(0.098-\mathrm{cm}$ thick). The 
welghts for the materfals that would have to be used in the components of the three reference cells are listed in Table 2; both the charged and uncharged

Table 2. Weights of Components in Li/FeSx Cells

\begin{tabular}{|c|c|c|c|c|c|c|c|}
\hline \multirow[b]{3}{*}{ Compor ent } & \multicolumn{7}{|c|}{ Component WeIght, $1 \mathrm{~b} / \mathrm{kW}-\mathrm{hr}$} \\
\hline & \multicolumn{2}{|c|}{ SES } & \multicolumn{2}{|c|}{ EV (FeS) } & \multicolumn{2}{|c|}{$\mathrm{EV}\left(\mathrm{FeS}_{2}\right)$} & \multirow{2}{*}{$\frac{\text { Mark IA }}{\text { Chgd. }}$} \\
\hline & Unchgd. & - Chgd. & Unchgd. & Chgd. & Unchd. & Chgd. & \\
\hline \multicolumn{8}{|l|}{ Electrode } \\
\hline Lithium & 0 & 0.67 & 0 & 0.67 & 0.06 & 0.57 & 0.66 \\
\hline Aluminum & 2.52 & 2.52 & 2.52 & 2.52 & 2.17 & $2 . .17$ & 3.10 \\
\hline $\mathrm{LI}_{2} \mathrm{~S}$ & 2.22 & 0 & 2.22 & 0 & 1.69 & 0 & 0 \\
\hline & 2.20 & 0 & 2.20 & 0 & 0.94 & 0 & 0 \\
\hline Fes & 0 & 3.75 & 0 & 3.75 & 0 & 0 & 3.79 \\
\hline $\mathrm{FeS}_{2}$ & 0 & 0 & 0 & 0 & 0 & 2.12 & 0 \\
\hline \multicolumn{8}{|l|}{ Electrolyte } \\
\hline LIC1 & 2.19 & 2.19 & 2.19 & 2.19 & 2.08 & 2.08 & 2.69 \\
\hline $\mathrm{KC1}$ & 2.79 & 2.79 & 2.79 & 2.79 & 1.92 & 1.92 & 3.40 \\
\hline \multicolumn{8}{|l|}{ Separator } \\
\hline BN & $\mathbf{0}$ & & $0.33^{a}$ & $0.33^{a}$ & $0.33^{b}$ & $0.33^{b}$ & $1.80^{\mathrm{C}}$ \\
\hline $\mathrm{MgO}$ & 1.95 & 1.95 & & & 0 & 0 & \\
\hline Jeg. Cur. Col. & 1.05 & 1.05 & 1.05 & 1.05 & 1.05 & 1.05 & 1.27 \\
\hline Pos. Cur. Col. & 1.05 & 1.05 & 1.05 & 1.05 & $0.33-0.50$ & $0.33-0.50$ & 1.21 \\
\hline Cell Can & 3.50 & 3.50 & 1.70 & 1.70 & 1.70 & 1.70 & 2.75 \\
\hline Feed through & 0 & 0 & & 0 & 0 & 0 & \\
\hline Miscellaneous & 2.53 & 2.53 & 1.88 & 1.88 & 1.47 & 1.47 & 1.64 \\
\hline Cel1 Wt. & 22.0 & 22.0 & 17.93 & 17.93 & 14.08 & 14.08 & 22.31 \\
\hline Li Content & 1.03 & 1.03 & 1.03 & 1.03 & 0.91 & 0.91 & 1.09 \\
\hline \multicolumn{8}{|c|}{${ }^{\mathrm{a}}$ Used $5 \mathrm{ft}^{2} / \mathrm{kW}-\mathrm{hr}\left(0.066 \mathrm{lb} / \mathrm{ft}^{2}\right)}$. \\
\hline \multicolumn{8}{|c|}{${ }^{c}$ BN cloth used as separator: $7.4 \mathrm{ft}^{2} / \mathrm{kW}-\mathrm{hr}$ at $0.24 \mathrm{lb} / \mathrm{ft}^{2}$. } \\
\hline \multicolumn{8}{|c|}{ 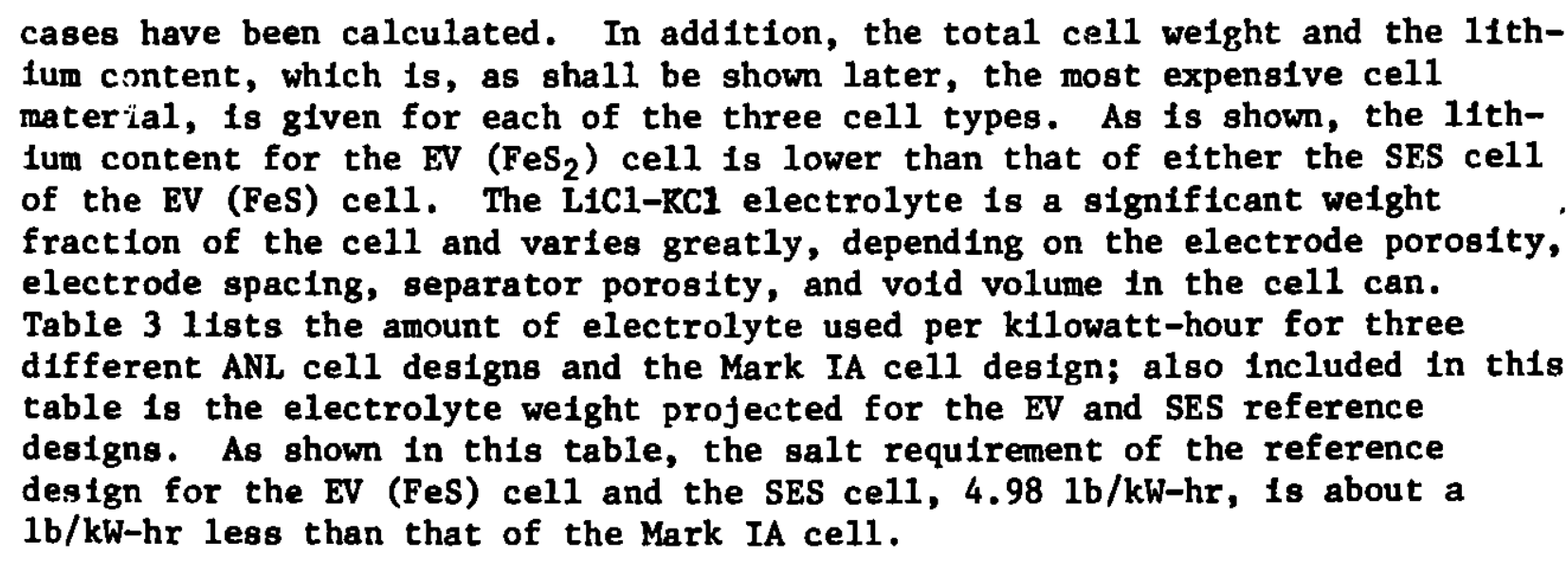 } \\
\hline
\end{tabular}


Table 3. Electrolyte Requirements for $\mathrm{L1} / \mathrm{FeS}$ Cel1s

\begin{tabular}{lc}
\hline Cell Type & $\begin{array}{c}\text { Electrolyte Content, } \\
\text { lb/kW-hr }\end{array}$ \\
\hline ANL Type M-MPa & 9.00 \\
ANL Type PWb & 6.56 \\
ANL Type KC & 5.47 \\
Mark IA Cell & 6.09 \\
SES Ref. & 4.98 \\
EV (FeS) Ref. & 4.98 \\
EV (FeS ${ }_{2}$ ) Ref. & 4.00
\end{tabular}

This is a multiplate cell (three positive and four negative electrodes) with BN felt separators; described further in ANL-79-39, p. 33.

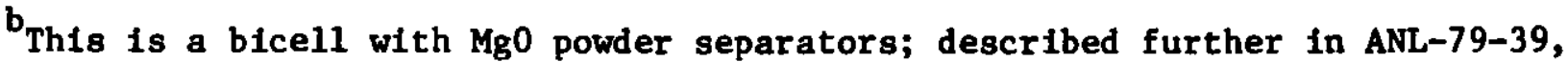
p. 32 .

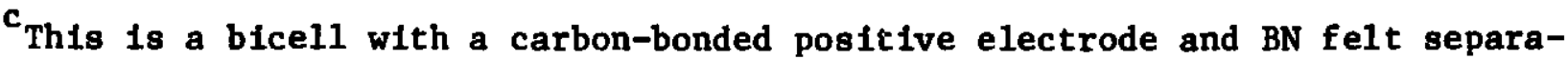
tor; described further in ANL-79-39, p. 32.

The current collector is a significant fraction of the total cell cost, and its weight per kllowatt-hour also varles greatly depending on the cell design. These current-collector weights are 11sted for three types of ANL cells and the Mark IA cell in Table 4; also included in this table are the

Table 4. Current Collector Welght for $\mathrm{L1} / \mathrm{FeS}$ Cells

\begin{tabular}{ccc}
\hline Type & \multicolumn{2}{c}{ Collector Weight, 1b/kW-hr } \\
\hline ANL Type PW & 2.05 & Neg. \\
ANL Type Ra & 1.34 & 2.05 \\
ANL Type K & 2.14 & 1.60 \\
Mark IA Cell & 1.27 & 0.86 \\
SES Ref. & 1.05 & 1.21 \\
EV (FeS) Ref. & 1.05 & 1.05 \\
EV (FeS ${ }_{2}$ ) Ref. & $0.33-0.50$ & 1.05 \\
\hline
\end{tabular}

${ }^{\text {This }}$ is a bicell assembled uncharged; described further in ANL-78-98, pp. 121-122.

current-collector welghts projected for the reference cell designs. Although the weight for the positive current collector of the K-type cells is the highest of the cells Iisted in Table 4, the weight of its negative current collector is lower than that required for all the reference cells. To date, the only current collector material found to be compatible with the highly 
corrosive $\mathrm{FeS}_{2}$ electrode is molybdenum; it is believed that molybdenum powder formed into an advanced current collector should reet the welght requirement given in Table $4(0.33$ to $0.50 \mathrm{lb} / \mathrm{kW}-\mathrm{hr})$. Although molybdenu 1 is an expensive material, its excellent corrosion resistance and high electrical conductivity does, to some extent, compensate for its high cost.

The price of several cell materials produced in low volumes was selected from a list of commodity prices in market publications that had been collected over the past several years. Where a price was obtained earlier than 1979, it was increased by $10 \%$ per year to account for inflation. From this 1 ist, we selected a high and low estimate for the cell material cost; these values are shown iln Table 5. For commercially avallable commodities in high volume, a single cost was taken from market publications. The costs for $\mathrm{BN}$ felt and $\mathrm{Li}_{2} \mathrm{~S}$ were not avallable in market 11terature. Therefore, the cost for $\mathrm{BN}$ felt was derived from projections made by Carborundum Corp.* for high-volume production. The cost projections for $\mathrm{Li}_{2} \mathrm{~S}$ were based upon discussions with knowledgable individuals in the lithium industry. The low value is the projected cost of $\mathrm{Li}_{2} \mathrm{~S}$ made from an intermediate product in the production of $\mathrm{Li}_{2} \mathrm{CO}_{3}$, and the higher value is for $\mathrm{LI}_{2} \mathrm{~S}$ produced by the battery manufacturer. The cost of plant equipment and labor for the in-house production of $\mathrm{LI}_{2} \mathrm{~S}$ would result in increased plant complexity. From the cost data in Table 5, we deduced that LiCl-KCl eutectic ( $i . e ., 44.2$ wt \% LiC1) would have a cost of $\$ 0.55$ to $\$ 0.75 / 1 \mathrm{~b}$ and FeS (a mixture of $\mathrm{FeS}_{2}$ and $\mathrm{Fe}$ powder) would have a cost of $\$ 0.10 / 1 b$.

From the data in Tables 2 and 5, the cost per k1lowatt-hour was determined for the five most expensive cell materials or components. These costs are shown in Table 6 . The most expensive materlal is lithium, the cost of which ranges from $\$ 4.61 / \mathrm{kW}-\mathrm{hr}$ for an uncharged cell up to $\$ 14.26 / \mathrm{kW}-\mathrm{hr}$ for a charged cell. Although the weight contribution of the BN felt to the EV cell is negligible, this materlal is expensive and represents a significant portion of the overall cell cost. Therefore, we estimated the amount of BN felt required in area per kilowatt-hour, and found this value to range from 4 $\mathrm{ft}^{2} / \mathrm{kW}-\mathrm{hr}$ for $\mathrm{FeS}_{2}$ cells to $5 \mathrm{ft}^{2} / \mathrm{kW}-\mathrm{hr}$ for $\mathrm{FeS}$ cells. Using this data and the BN felt costs given in Table 4, we were able to estimate the cost per kilowatt-hour for $\mathrm{BN}$ felt in the EV cell ( $\$ 4.00$ to $8.50 / \mathrm{kW}-\mathrm{hr}$ ).

\section{B. Costs for Plant, Production Equipment, and Labor}

The basic costs for equipment and labor were taken from the earlier cost study (ANL-76-12, pp. 11-12) and then scaled to account for inflation, EV cell size (much smaller than the SES cell), and EV cell plant complexity. A brief summary of the equipment and labor costs (in 1976 dollars) determined for the original plan $(1,150 \mathrm{MW}-\mathrm{hr} / \mathrm{yr})$ is given in Table 7 . It is common industrial practice to use scaling factors to reflect such things as inflation, a change in size, the change in production volume, etc. to provide an updated estimates of costs. Such factors were used to update ANL-76-12. The four scaling factors employed in this report are discussed below.

\footnotetext{
* Carborundum is fabricating the BN felt presently used in Li/MS cells.
} 
Table 5. A Range of Material Costs for LI/FeS Cells

\begin{tabular}{|c|c|c|}
\hline Material & Cost, $a / 1 b$ & Source \\
\hline \multirow[t]{2}{*}{ L1 Metal } & 10.31 (1ow) & (1975) Foote Mineral Co. \\
\hline & 15.90 (high) & (1979) Chem. Market News. \\
\hline \multirow[t]{2}{*}{ L1C1 } & 1.20 (1ow) & Extraction from brineṣ. \\
\hline & 1.65 (high) & (1979) Chem. Market News. \\
\hline \multirow[t]{2}{*}{ KC1 } & 0.02 (low) & (1979) Chem. Market Reporter. \\
\hline & 0.03 (high) & \\
\hline \multirow[t]{2}{*}{$\mathrm{LI}_{2} \mathrm{~S}$} & 1.25 (low) & $\begin{array}{l}\text { Production from } \mathrm{LI}_{2} \mathrm{CO}_{3} \\
\text { intermediate. }\end{array}$ \\
\hline & 1.55 (high) & Produced from $\mathrm{LI}_{2} \mathrm{CO}_{3}+\mathrm{H}_{2} \mathrm{~S}$. \\
\hline $\mathrm{Li}_{2} \mathrm{CO}_{3}$ & 0.95 & (1979) Chem. Market News. \\
\hline BN Felt & $\begin{array}{l}1.00\left(^{(1 o w)}\right)^{b} \\
1.70\left(\text { high }^{b}\right.\end{array}$ & Carborundum Corp. estimates. \\
\hline \multirow[t]{2}{*}{ Mg0 } & 0.25 (low) & Martin-Marietta Corp. \\
\hline & 0.50 (hIgh) & T. OlszanskI (ANL). \\
\hline Aluminum Sheet & 0.57 & $\begin{array}{l}\text { (1979) Minerals \& Metals } \\
\text { (U.S. Bur. Mines) }\end{array}$ \\
\hline $\begin{array}{l}\mathrm{FeS}_{2} \\
\text { (pyrites, } 20 \text { mesh) }\end{array}$ & 0.07 & CE Minerals (1975). \\
\hline Fe Powder & 0.175 & Amertcan Metal Market. \\
\hline Low-Carbon Steel & 0.33 & Steel Sales Corp. (1975). \\
\hline Steel Sheet & 0.195 & $\begin{array}{l}\text { (1979) Min. Mat'1s, U.S. } \\
\text { Bu. of Mines }\end{array}$ \\
\hline Mo Powder & 4.40 & (1979) Chem. Market News. \\
\hline Fe-5\% Mo Sheet & 0.70 & J. Battles (ANL). \\
\hline Feedthrough Components & $2.40^{c}$ & J. Battles (ANL). \\
\hline
\end{tabular}


Table 6. Most Expensive Materials in $\mathrm{L}_{1} / \mathrm{FeS}_{\mathrm{x}} \mathrm{Cel1}$

\begin{tabular}{ll}
\hline \multicolumn{1}{c}{ Material } & \multicolumn{1}{c}{ Cost, \$/kW-hr } \\
\hline L1 or Li Compounds & $4.61-14.26$ \\
BN Felt (Separator) & $4.00-8.50$ \\
Feedthrough Parts & 2.40 \\
Mo Powder (Current Collector) & $1.45-2.20$ \\
A1 (Negative Electrode) & $1.43-1.66$ \\
\hline
\end{tabular}

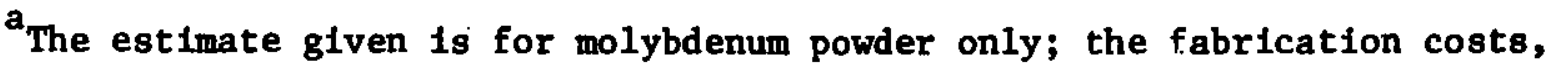
based upon est1mates by Rockwell International, are expected to be a small fraction of the material cost.

Table 7. Equipment and Labor Costs for SES Cel1 ${ }^{1}$ (1976 dollars)

\begin{tabular}{|c|c|}
\hline Equipment and Labor & Cost, $\$ \times 10^{6}$ \\
\hline $\begin{array}{l}\text { Production and ancillary equipment } \\
\text { Land, buildings, and installation } \\
\text { Inventory and work in progress } \\
\text { Other cash required }\end{array}$ & $\begin{array}{l}3.204 \\
6.408 \\
1.922 \\
1.000 \\
\end{array}$ \\
\hline Total & 12.534 \\
\hline $\begin{array}{l}\text { Direct labor including fringe benefitsc } \\
\text { Indirect labor, and indirect operating costsd }\end{array}$ & $\begin{array}{l}1.404 \\
2.160 \\
\end{array}$ \\
\hline Total & 3.564 \\
\hline
\end{tabular}

$a_{\text {Twice }}$ the cost of operating equipment.

${ }^{b}$ About $20 \%$ of the cost of equipment, land, and buildings, which corresponds to approximately one month's supply of raw or converted materials.

${ }^{C}$ Direct labor calculated assuming a $\$ 6 / \mathrm{hr}$ rate; fringe benefits were assumed to be $30 \%$ of direct labor.

dindirect labor costs (supervision, clerical, maintenance, etc.) and operating costs (fuel, power, etc.) were assumed to be twice the direct labor cost.

(1) Inflation Factor. The materials costs for the prevlous cost study was gathered in early 1975, or approximately 4 years ago. Allowing $10 \%$ per year for inflation, this factor is $(1.10)^{4}$ or 1.46 . 
(2) Cell-Size Factor. The effect of the cell size can be approximated by considering some exponential function of cell volume. Because the cell size is thought to have only a small effect on production equipment and labor, the equation $\mathrm{f}=(\mathrm{V})^{0.2}$ (where $\mathrm{V}$ is the cell volume) was utilized to determine the cell size factor. Since the EV reference cell is about $50 \%$ less in volume than the SES reference cell used for ANL-76-12, then the cell-s1ze factor for the EV cell is $(0.5)^{0.2}=0.87$.

(3) Cell-Production-Rate Factor. The number of cells produced per unit time has a signiflcant effect on the cost of production equipment and labor. A plant producing cells of a large size would have a smaller number of unit operations and would, therefore, be expected to have a lower equipment and labor cost than that of a plant producing smaller cells. A scallng factor of (N) 0.8 was used in this study to estimate the Increased cost of equipment and labor for an EV cell compared to the 1976 SES cell. For the EV cells, the factor was taken to be $(2)^{0.8}=1.74$.

(4) Plant Complexity Factor. The plant design described in ANL-76-12 was based upon a production scheme that has been superceded by a much simpler one. In the new scheme, recently developed rolling or pressing operations are used to mass produce electrodes. As a result of the simplifications now foreseen, we estimated a lower IImit for plant complexity of 0.75 , based upon 1.0 as the normalized value for the 1976 plant. An upoer 11mit for plant complexity of 1.25 was then taken to allow for unanticloated process steps.

For convenience, the scaling factors used to update the equipment and labor costs determined for 1976 are shown in Table 8 for each reference design.

Table 8. Scaling Factors for SES and EV Cells

\begin{tabular}{|c|c|c|c|c|c|c|}
\hline \multirow[b]{2}{*}{ Scaling Factor } & \multicolumn{2}{|c|}{ SES Ce11 } & \multirow{2}{*}{$\frac{\mathrm{EV}(\mathrm{FeS})}{\text { Low }}$} & \multirow{2}{*}{$\frac{\mathrm{Ce} 11}{\text { HIgh }}$} & \multicolumn{2}{|c|}{ EV $\left(\mathrm{FeS}_{2}\right) \mathrm{Ce} 11$} \\
\hline & Low & High & & & Low & High \\
\hline $\begin{array}{l}\text { Inflation } \\
\text { Cell size and production } \mathrm{r}^{-}= \\
\text {Production complexity }\end{array}$ & $\begin{array}{l}1.46 \\
1.0 \\
0.75\end{array}$ & $\begin{array}{l}1.46 \\
1.0 \\
1.25\end{array}$ & $\begin{array}{l}1.46 \\
1.51 \mathrm{a} \\
0.75\end{array}$ & $\begin{array}{l}1.46 \\
1.51 \mathrm{a} \\
1.25\end{array}$ & $\begin{array}{l}1.46 \\
1.51 \mathrm{a} \\
0.75\end{array}$ & $\begin{array}{l}1.46 \\
1.51^{\mathrm{a}} \\
1.25\end{array}$ \\
\hline
\end{tabular}

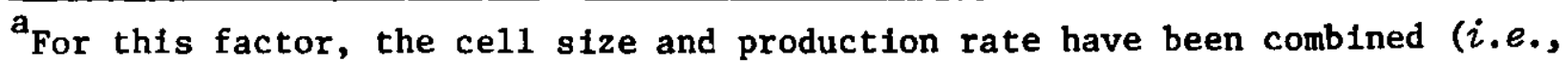
$0.87 \times 1.74=1.51)$.

\section{Cell Manufacturing Cost}

To calculate the total manufacturing cost for a reference cell, the following steps were followed. First, the equipment and labor costs given in ANL-76-12 were updated with the scaling factors given in Table 8. Second, the factory cost $(\$ / \mathrm{kW}-\mathrm{hr})$ was determined by adding together the basic materials cost for the cell (see Section III. A), the assumed material losses during fabrication $(1(\%)$, and the labor costs. Th1rd, the return on investment was estimated to yield $25 \%$ on the capital investment: ( $i . e .$, equipment, inventory, cash requirements, etc.) before taxes. Finally, the total 
manufacturing cost was calculated by adding together the factory cost, return on Investment and general and administrative costs (assumed to be $11 \%$ of factory cost). Table 9 presents a complete breakdown of these cost components

Table 9. Cost Calculation for EV (FeS) Cell Produced in a $1.15 \times 10^{6} \mathrm{~kW}-\mathrm{hr} / \mathrm{yr}$ Plant

I. Equipment Cost, $\$ / y r \times 10^{6}$

Production and ancilliary equipment

Land, Bldgs., Inst1. (200\%)

Total

Depreciation at $7.2 \%$

10.572

15.858 .

II. Labor Plus Overhead Costs, $\$ / y r \times 10^{6}$

Labor plus overheada (direct, fringes, indirect, superviston)

Depreciation

III. Factory Cost, $\$ / \mathrm{kW}-\mathrm{hr}$

Basic Materials Cost

17.24

Material Losses (10\%)

1.72

Labor \& Overhead

6.10

Factory Cost

$\overline{25.06}$

IV. Return on Investment (ROI), $\$ / \mathrm{kW}-\mathrm{hr}$

Investment

Depreclation Base $\mathrm{b}^{\mathrm{b}}$

Inventory \& work in progress $c$

2.192

Cash Requirements

Total

1.500

ROId

19.55

4.88

v. Wholesale Selling Price, $\$ / k W-h r$

Factory cost

25.06

General and Adiitnistrative (G\&A)e

ROI

Price

$\frac{4.88}{32.69}$

apdated cost from ANL-76-12, p. 12 .

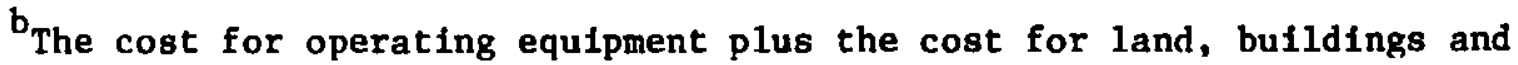
installation.

c Assumed to be $8.75 \%$ of factory cost.

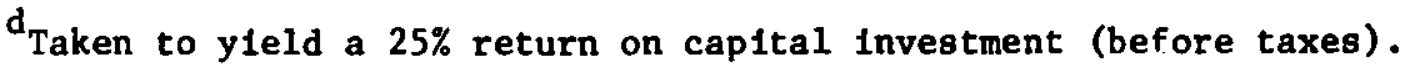

e Assumed to be $11 \%$ of factory cost. 
(low estimate) for the uncharged EV (FeS) cell; this type of EV cell is expected to be commercialized first. As shown, the materials cost for this ce11, $\$ 17.24 / \mathrm{kW}-\mathrm{hr}$, is about $53 \%$ of the manufacturer's wholesale selling price of $\$ 32.60 / \mathrm{kW}-\mathrm{hr}$.

A more general breakdown of the cost components for the SES cell and both EV cells is shown in Table 10 on the next page; a low and high cost estimate is made for each cost component. The table shows that the SES reference cell costs about $\$ 24$ to $41 / \mathrm{kW}-\mathrm{hr}$, the 1976 estimate being about $\$ 29 / \mathrm{kW}-\mathrm{hr}$. The estimated cost for the $\mathrm{EV}$ cells are about $\$ 31$ (uncharged) to $\$ 55$ (charged) per kilowatt-hour. The higher manufacturing cost calculated for the EV cells results from the higher cost assoctated with the BN felt separator (the 1979 SES cell was assumed to have a MgO powder separator) and the higher labor and equipment costs associated with the manufacture of a smaller cell.

Fig. 2 presents bar graphs of the cost data glven in Table 10 for the

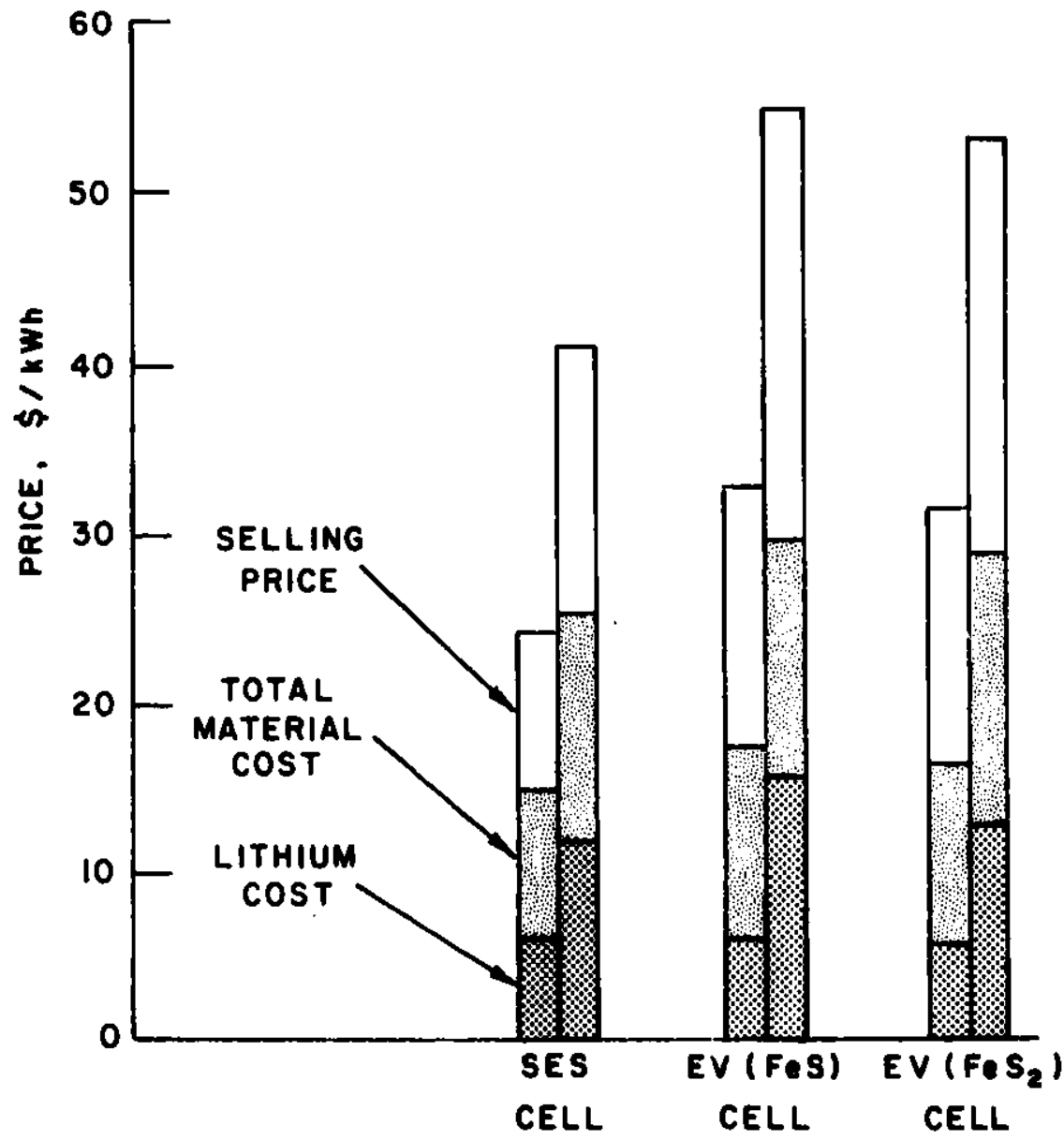

Fig. 2. Cost Estimates for SES and EV Cells (for each cell type, the column on the left represents the low estimate and that on the right represents the high estimate). 
Table 10. Cell Manufacturing Cost Sumary

\begin{tabular}{|c|c|c|c|c|c|c|c|}
\hline & \multirow{3}{*}{$\frac{1976 \text { Estimate }}{\text { of SES Cel1 }}$} & \multicolumn{6}{|c|}{ Present Estimate } \\
\hline & & \multicolumn{2}{|c|}{$\overline{\text { SES Cell }}$} & \multicolumn{2}{|c|}{$\mathrm{EV}(\mathrm{FeS}) \mathrm{Ce} 11$} & \multicolumn{2}{|c|}{ EV $\left(\mathrm{FeS}_{2}\right) \mathrm{Cell}$} \\
\hline & & Low & High & Low & High & Low & High \\
\hline $\begin{array}{l}\text { Equipment, } \$ \times 10^{6} \\
\text { Land, bldgs, } 1 \text { inst., } \$ \times 10^{6} \\
\text { Labor, } \$ \times 10^{6} \\
\text { Total Investment, } \$ \times 10^{6}\end{array}$ & $\begin{array}{r}3.20 \\
6.40 \\
3.56 \\
12.53\end{array}$ & $\begin{array}{r}3.51 \\
7.01 \\
3.90 \\
13.82\end{array}$ & $\begin{array}{r}5.85 \\
11.69 \\
6.50 \\
21.69\end{array}$ & $\begin{array}{r}5.28 \\
10.57 \\
5.88 \\
19.55\end{array}$ & $\begin{array}{r}8.81 \\
17.62 \\
9.80 \\
31.62\end{array}$ & $\begin{array}{r}5.28 \\
10.57 \\
5.88 \\
19.44\end{array}$ & $\begin{array}{r}8.81 \\
17.62 \\
9.80 \\
31.53\end{array}$ \\
\hline $\begin{array}{l}\text { Materials Cost, } \$ / \mathrm{kW}-\mathrm{hr} \\
\text { Factory Cost, } \$ / \mathrm{kW}-\mathrm{hr} \\
\mathrm{ROI}, \$ / \mathrm{kW}-\mathrm{hr}\end{array}$ & $\begin{array}{r}19.02 \\
26.27 \\
2.89\end{array}$ & $\begin{array}{r}14.76 \\
20.88 \\
3.46\end{array}$ & $\begin{array}{r}25.05 \\
35.30 \\
5.42\end{array}$ & $\begin{array}{r}17.24 \\
27.81 \\
4.88\end{array}$ & $\begin{array}{r}29.63 \\
46.86 \\
7.91\end{array}$ & $\begin{array}{r}16.14 \\
26.47 \\
4.86\end{array}$ & $\begin{array}{r}28.64 \\
45.65 \\
7.88\end{array}$ \\
\hline Selling Price, \$/kW-hr & 29.16 & 24.34 & 40.72 & 32.69 & 54.77 & 31.33 & 53.53 \\
\hline
\end{tabular}

Manufacturing cost from ANL-76-12. 
SES and EV cells. The total materials cost for each cell, also shown in this f1gure, represents about 52 to $65 \%$ of the total cell cost. The most expensive cell materlals were found to be lithluin (metal and compounds), $\$ 4.61$ to 14.26 / $\mathrm{kW}-\mathrm{hr}$, and BN felt, $\$ 4.00$ to $8.50 / \mathrm{kW}-\mathrm{hr}$. If the projected cost for 11thium of $\$ 4.61 / \mathrm{kW}-\mathrm{hr}$ can be reached, then the Li:FeS system would be highly competitive with all other advanced battery systems. Consequently, the lithium cost would not be a dominant obstacle to cormercialization.

\section{A COMPARISON BETWEEN ANI AND ARTHUR D. LITTLE (ADL) MANUFACTURING COST METHODOLOGY}

The Department of Energy has recommended that the ADL manufacturing cost methodology ${ }^{3}$ be used for estimating the manufacturing costs for advanced batteries for utility load-leveling. Accordingly, the manufacturing cost for the SES reference cell was made by the ADL method and compared with the cost estimated by the ANL procedure. Some of the important features of both methodologies are discussed below.

Materlal Allowance. Both reports show a 5\% material allowance for scrap; however, to be conservative, we have changed this figure to a $10 \%$ allowance.

Overhead. In the ANL method, the overhead was determined by adding together the cost for fringe benefits, indirect labor (e.q., supervision, maintenance, clerical) and operating costs (e.g., fuel, power), and depreciation of equipment and bulldings. For these cost factors, the fringe benefits were assumed to equal $30 \%$ of the direct labor cost; indirect labor and operating costs were assumed to equal twice the direct cost; and depreciation was assumed to be $7.2 \%$ of the equipment and buildings. In the ADL method, overhead was calculated by adding up $150 \%$ of direct labor cost, $10 \%$ of total materials, and depreciation ( $10 \%$ of equipment plus installation costs). The cost of land and buildings was not considered as part of the overhead. To account for land, building and installation, the ADL method includes rental as an operating cost.

Working Capital. The ANL method employed $10.7 \%$ of the annual factory cost based upon the expectation that the battery market would be well defined and would require minimal stock inventory. The ADL method employs $30 \%$ of annual factory cost for working capital.

Return on Capital Investment (ROI). The two methods are not very far apart on this factor. For the ANL method, a before-tax ROI of 25\%, corresponding roughly to $12.5 \%$ after taxes, was assumed; the ADL method specifies $15 \%$ after taxes. However, the investment base in the ADL method is sthaller than that of the ANL method because the cost of land and buildings is not included. The net effect is to make the ROI for the ADL method look larger. However, ADL made no explicit allowance for general and administrative cost. 
Production Rate. The production rate used for the ADL method was 2.5 million kW-hr/yr, whereas that of the ANL method was 1.15 million $\mathrm{kW}-\mathrm{hr} / \mathrm{yr}$. The latter rate was chosen to colncide with that used in ANL-76-12.

Labor Rate. For the ADL method, a labor rate of $\$ 7.50$ (in mid-1976 dollars) per hour was determined. At a $10 \%$ annual inflation rate, this amonints to a $\$ 6.49$ per hour rate for January, 1975 , whlch 1 s the date at which the labor rate was determined for $A N L-76-12(\$ 6.00 / h r)$. In 1979 dollars, these labor rates are $\$ 8.78 / \mathrm{hr}$ and $\$ 9.50 / \mathrm{hr}$ for the ANL and ADL methods, respectively.

A comparison of manufacturing costs for the SES cells are shown in Table 11 for both methods; as can be seen, the difference in manufacturer's selling price is minimal, less than about $\$ 1 / \mathrm{kW}-\mathrm{hr}$.

Table 11. The SES Cell Manufacturing Cost According to Two Costing Methodologles (1979 Dollars)

\begin{tabular}{|c|c|c|}
\hline Cost Item & ANL Method ${ }^{2}$ & ADL Method ${ }^{3}$ \\
\hline $\begin{array}{l}\text { Equipment Cost, } \$ \times 10^{6} \\
\text { Deprec atition Buse, } \$ \times 10^{6} \\
\text { Total Investment, } \$ \times 10^{6}\end{array}$ & $\begin{array}{c}4.678 \\
14.03 \\
17.46-18.05\end{array}$ & $\begin{array}{c}4.678 \\
9.356 \\
16.27-18.44\end{array}$ \\
\hline $\begin{array}{l}\text { Total Labor, } \$ / \mathrm{kW}-\mathrm{hr} \\
\text { Labor \& Overhead, } \$ / \mathrm{kW}-\mathrm{hr} \\
\text { Bulld1ng Rental, } \$ / \mathrm{kW}-\mathrm{hr} \\
\text { Mat'ls Cost Range, } \$ / \mathrm{kW}-\mathrm{hr} \\
\text { Factory Cost plus G\&A, } \$ / \mathrm{kN}-\mathrm{hr} \\
\text { ROI, } \$ / \mathrm{kW}-\mathrm{hr}\end{array}$ & $\begin{array}{c}5.20 \\
6.21 \\
0 \\
15.95-22.55 \\
24.60-31.92 \\
4.36-4.51\end{array}$ & $\begin{array}{c}4.27 \\
5.20 \\
0.27 \\
15.95-22.55 \\
23.02-30.28 \\
4.88-5.53\end{array}$ \\
\hline Wholesale Selling Price, $\$ / k W-h r$ & $28.96-36.43$ & $27.90-35.81$ \\
\hline
\end{tabular}

V. LITHIUM RESOURCES AND REOUIREMENTS

\section{A. Reserves/Resources Lithlum}

A classification system designed to express resource data estimates was developed by the Bureau of Mines and the U.S. Geological Survey and publishec in 1976 in Geological Survey Bulletin 1450-A. This system defines a reserve as that part of a resource for which rank, quality, and quantity have been reasonably determined and which is deemed to be minable at a profit under existing market condftions. A resource is defined as an estimated quantity of a commodity in the ground in such form that economic extraction is or may become feasible. Reserve estimates, based on data from private industry and from the U.S. Geological Survey and other governmental agencies, are given in Table 12. The reserve in Table 12 includes these reserves as well as 11 thlum resources that may be only marginally economic. This table includes only those resources recoverable using existing technology; hypothetical (undiscovered) resources are not included. 
Table 12. Identified World Lithium Resourcesa

\begin{tabular}{lccc}
\hline & \multicolumn{2}{c}{$10^{3}$ Short } & Tons of Lithium \\
\cline { 2 - 4 } Country & Reserve Base & Otherc & Total \\
\hline United States & 400 & 400 & 800 \\
Canada & 200 & 300 & 500 \\
Chile, Bolivia, Brazil & 1003 & 3117 & 4120 \\
Africa, Europed, Asiad, Australia & 497 & 2083 & 2580 \\
World Total & 2100 & 5900 & 8000 \\
\hline
\end{tabular}

a Based on Information in Ref. 4.

${ }^{b}$ Lithium contained in ore deliverdd to the mill head; about $66 \%$ of this lithium is recoverable as chemicals.

${ }^{c}$ Resources recoverable using existing technology; derived in consultation with J.S. Geologic Survey.

dorder of magnitude only.

Most of the world's lithium reserve base, totaling about 2.1 million tons of recoverable 11thium dellvered to a miil head, are in subsurface brines in Chile and in pegmatites in the United States, Canada, Zaire, and the U.S.S.R. The Chilean brines, investigated recently on a pilot scale, represent about one-half of world reserves. Approximately one-sixth of the world's Ifthlum reserve base is in North Carolina, in the Carolina lithium belt. Total estimated world resources are approximately 8 million tons of 1 ithium equivalent. An estimated two-thirds of the lithium contained in the ore delivered to the mill head is recoverable as chemicals.

\section{B. Lithium Requirements}

The projected lithium requirements for both conventional uses and Li/FeS batteries are given in Table 13. The annual prodiction requirements between 1986 and 2006 were estimated in five year intervals. The 11thium requirements for batteries in each period is estimated from present projections of the state of Li/Fes technology. In the 1986-1990 perlod, it is expected that a pilot production line at one or two commerclai manufacturers will be producing EV L1/FeS batteries for limited markets. In the next period, one or more partially automated plants are expected. In the third period, 1996-2000, several fully-automated plants producing $6000 \mathrm{MW}-\mathrm{hr} / \mathrm{yr}$ (enough for 200,000 automoblles/yr) are projected. Because the present strategy is to base the development of the SES battery upon EV battery technology, second-generation SES batterles are not expected to emerge unt11 the 1996-2000 period. A plant of $2500 \mathrm{MW}-\mathrm{hr}$ capacity could produce 25 SES batteries per year in the pertod 2001-2005.

As shown in Table 13, the cumulative 11thium requirements for batteries and conventional uses are projected to be 275,240 short tons by 2006 . Th1s value represents $51 \%$ of the total U.S. resources (approx 2 mately $100 \%$ of the 
Table 13. Projected Lith1um Requirements for the U.S.A.

\begin{tabular}{|c|c|c|c|c|}
\hline & $1986-1990$ & 1991-1995 & $1996-2000$ & 2001-2005 \\
\hline \multicolumn{5}{|l|}{ SES Batterfes (100 MW-hr) } \\
\hline $\begin{array}{l}\text { Number/yr } \\
\text { Production Capacity, MW-hr/yr }\end{array}$ & $\begin{array}{l}0 \\
0\end{array}$ & $\begin{array}{r}1 \\
100\end{array}$ & $\begin{array}{r}3 \\
300\end{array}$ & $\begin{array}{r}25 \\
2500\end{array}$ \\
\hline \multicolumn{5}{|l|}{ EV Batteries (30 kW-hr) } \\
\hline $\begin{array}{l}\text { Number/yr } \\
\text { Production Capacity, MW-hr/yr }\end{array}$ & $\begin{array}{r}1000 \\
30\end{array}$ & $\begin{array}{r}12,000 \\
360\end{array}$ & $\begin{array}{r}200,000 \\
6,000\end{array}$ & $\begin{array}{r}1,000,000 \\
30,000\end{array}$ \\
\hline $\begin{array}{l}\text { Total Annual Production, MW-hr } \\
\text { Lithium, short tons per } 5 \text { yr pe }\end{array}$ & 30 & 460 & 6,300 & 32,500 \\
\hline For Batteries & 75 & 1150 & 15,750 & 81,250 \\
\hline For Conventional Uses & 30,000 & 37,500 & 50,000 & 66,900 \\
\hline Total per period & 30,075 & 38,650 & 65,750 & 148,150 \\
\hline
\end{tabular}

reserve base) or $5.1 \%$ of the known world resource*. Of the total 11thium used in battery production, about $93 \%$ would go to $\mathrm{EV}$ batteries and about $7 \%$ to SES batteries. Of the total 11thium produced to the year 2006 , 33\% would be used in battery production, the remaining $67 \%$ would be consumed in conventional uses. Based upon this high projected lithlum requirement, it is expected that a very large fraction (perhaps $>90 \%$ ) of the 11thfum in batterles would be recycled.

\section{CONCLUDING REMARKS}

The major assumptions that need to be demonstrated to confirm the low cost potentlal of $\mathrm{LI}-\mathrm{Al} / \mathrm{FeS}$ cells are as follows:

1. that lithium sulfide can be produced at about the same cost as Ifthium carbonate from a lithlum carbonate intermediate product (the production of $\mathrm{LI}_{2} \mathrm{~S}$ from $\mathrm{LI}_{2} \mathrm{CO}_{3}$ plus $\mathrm{H}_{2} \mathrm{~S}$ is another, somewhat more expensive alternative);

2. that low-cost current collectors for the positive electrode in the $\mathrm{L1}-\mathrm{Al} / \mathrm{FeS}_{2}$ ceil can be manufactured from molybdenum powders or Iron substrates coated with a low-cost ceramic materlal;

\footnotetext{
*For these calculations, losses of 11thium due to conversion to chemicals are included.
} 
3. that BN felt can be produced at about $\$ 1.00 / \mathrm{ft}^{2}$ in mass production;

4. that low-cost, long-1ifetime, and Inexpensive alloys can be developed for the current collectors in the $\mathrm{L} 1-\mathrm{Al} / \mathrm{FeS}$ cell and for the cell can;

5. that electrode particle retention can be accomplished by low-cost materials such as photo-etched sheets backed up by BN felt (the present use of screens and $\mathrm{ZrO}_{2}$ or $\mathrm{Y}_{2} \mathrm{O}_{3}$ cloth for th1s purpose is too expensive for commerclal application);

6. that the labor and equipment costs are in the range projected by this study (the earliest check of this w1ll be when the L1/Fes cell is manufactured in a pilot plant, but final confirmation will not be possible until a fully automated plant has been built and operated).

For the high estimates of cell cost, certain limited market applications for the LI/FeS battery appear within reach, such as vans, buses, mining vehicles and submarines. The low estimates for both the SES and EV cells are within the cost goals set by DOE and ANL, and. If these costs can be attained, successful commerclalization of the Li/Fes battery ior stationary and vehicle applications would be expected on a large scale. 


\section{ACKNOWLEDGEMENTS}

Th1s work was carried out under the sponsorship of the U.S. Department of Energy, Division of Energy Storage Systems. 


\section{REFERENCES}

1. W. L. Towle et al., Cost Estimate for the Commercial Monufacture of Lithizm/Iron Sulfide Cells for Load-Leveling; Argonne National Laboratory Report, ANL-76-12 (March 1976).

2. P. A. Nelson et al., Lithium-Iron Sulfide Batteries for Electric Vehicles, Proceedings of the Fifth International Electric Vehicle Symposium, October 2-5, 1978, Ph1ladelphia, PA (1978).

3. J. H. B. George, Proposed Criteria for Estimating the Capital Costs of Advancec Battery Systems for Utility Energy Storage, Electric Power Research Institute Interim Report EPRI-787-1 (an Arthur D. LIttle Study) (November 1975).

4. R. H. Singleton, Lithizm, Bureau of Mines mineral commodity profile, U.S. Dept. of the Inter lor, September 1979. 
Iaternal:
W. E. Massey
M. V. Nevitt
P. R. Fields
S. A. Davis
B. R. T. Frost
G. T. Garvey
J. J. Roberts
K. E. Anderson
J. D. Arntzen
B. Bandyopadhyay
J. Barghusen
D. L. Barney (25)
L. Bartholme
J. E. Battles
E. C. Berrill
L. Burris
F. A. Cafasso
A. A. Chilenskas (25)
P. Cunningham
W. DeLuca
P. A. Eident
R. Elliott
P. Eshman
M. K. Farahat
A. K. Fischer
E. C. Gay
J. D. Geller

J. E. A. Grage

J. Harmon

E. R. Hayes

F. Hornstra

A. A. Jonke

T. D. Kaun

R. W. Kessie

G. M. Kesser

J. E. Kincinas

V. M. Kolba

W. Kremsner

M. L. Kyle

W. W. Lark

S. Lawroski

R. F. Malecha

F. J. Martino

C. A. Melendres

A. Melton

W. E. Miller

F. Mrazek

K. M. Myles

Z. Nagy

P. A. Nelson (50)

N. Otto

E. G. Pewitt

R. B. Poeppel
S. Preto

G. Redding

K. A. Reed

M. F. Roche

L. E. Ross

M. Saboungi-Blander

W. W. Schertz

J. L. Settle

H. Shimotake

M. A. Slawecki

J. A. Smaga

R. K. Steunenberg

S. Susman

B. Swaroop

C. A. Swoboda

C. Sy

Z. Tomezuk

R. Varma

D. R. Vissers

S. Vogler

D. S. Webster

S. E. Wood

N. P. Yao

A. B. Krisciunas

ANL Contract File

ANL Libraries (5)

TIS Files (6)

\section{External:}

DOE-TIC, for distribution per UC-94cb (334)

Manager, Chicago Operations and Regional Office, DOE

Chief, Office of Patent Counsel, DOE-CORO

V. Hummel, DOE-CORO

W. R. Frost, DOE-CORO

President, Argonne Universities Association

Chemical Engineering Division Review Committee:

C. B. Alcock, U. Toronto

R. C. Axtmann, Princeton U.

J. T. Banchero, U. Notre Dame

T. Cole, Ford Motor Corp.

P. W. Gilles, U. Kansas

R. I. Newman, Warren, N. J.

H. Perry, Resources for the Future, Washington

G. M. Rosenblatt, Pennsylvania State U.

W. L. Worrell, U. Pennsylvania

E. Adler, Hughes Aircraft Co., El Segundo

J. G. Ahlen, Illinuis Legislative Council, Springfield

J. W. Alpha, Corning Glass Works, Corning, N. Y.

J. Ambrus, Naval Surface Weapons Center, Silver Spring, Md.

J. N. Anand, Dow Chemical Co., Walnut Creek, Calif. 
F. Anson, California Inst. Technology

B. Askew, Gould Inc., Rolling Meadows, Ill.

P. Auh, Brookhaven National Lab.

H. Balzan, Tennessee Valley Authority, Chattanooga

K. F. Barber, Div. Electric and Hybrid Vehicle Systems, USDOE

H. J. Barger, Jr., U. S. Army MERDC, Fort Belvoir

R. W. Barnes. Lithium Corp. of America, Gantonia, N. C.

T. R. Beck, Elisctrochemical Technology Corp., Seattle

M. Benedict, Massachusetts Inst. Technology

D. N. Bennion, U. California, Los Any, eles

J. Birk, Electric Power Research Inst.

J. Braunstein, Oak Ridge National Lab.

M. Bieiter, GE Research \& Development Center, Schenectady

J. O. Brittain, Northwestern U.

R. Brodd, Parma Technical Center, Union Carbide Corp.

J. J. Brogan, Div. Highway Systems, USDOE

E. Brooman, Battelle Memorial Inst., Columbus

B. D. Brummet, McGraw-Edison Co., Bloomfield, N. J.

M. C. Burton, Delco Remy, Anderson, Ind.

D. M. Bush, Sandia Laboratories

E. Buzzelli, Westinghouse Electric Corp., Pittsburgh

E. J. Cairns, Lawrence Berkeley Lab.

E. Carr, Eagle-Picher Industries, Joplin

P. Carr, Energy Development Associates, Madison Heights, Mich.

Chloride Systems (U. S. A.) Inc., North Haven, Conn.

C. Christenson, Gould Inc., Rolling Meadows, Ill.

M. Cohen, U. Chicago

A. R. Cook, Int'] Lead Zinc Research Organization, Inc., New York City

G. Coraor, E. I. duPont de Nemours \& Co., Wilmington

D. R. Craig, Hooker Chemical Corp., Orchard Park, N. Y.

G. Cramer, Southern California Edison, Rosemead

F. M. Delnick, Sandia Labs.

H. Dietrich, Fiber Materials, Inc., Biddeford, Mass.

D. L. Douglas, Electric Power Research Inst.

E. Dowgiallo, MERADCOM, Ft. Belvoir

J. Dunning, General Motors Research Lab., Warren, Mich.

P. Eggers, Battelle Memorial Inst., Columbus

M. Eisenberg, Electrochimica Corp., Mountain View, Calif.

R. P. Epple, Div. Materials Sciences, USDOE

H. R. Espig, Gould Inc., Rolling Meadows, Ill.

D. T. Ferrell, Jr., ESB Inc., Yardley, Pa.

P. L. Fleischner, National Beryllia Corp., Haskell, N. J.

J. H. B. George, Arthur D. Little, Inc., Cambridge, Mass.

J. Giner, Giner, Inc., Waltham, Mass.

G. Goodman, Globe-Union, Inc., Milwaukee

G. Gorten, Gorten and Associates, Sherman Oaks, Calif.

H. Grady, Foote Mineral Co., Exton, Pa.

S. Gratch, Birmingham, Mich.

D. Gregory, Inst. Gas Technology, Chicago

N. Gupta, Ford Motor Co., Dearborn, Mich.

N. Hackerman, Rice U.

G. Hagey, Div. of Environmental Impacts, USDOE

R. Hamilton, Carborundum Co., Niagara Falls

W. Hassenzahl, Los Alamos Scientific Laboratory 
L. A. Heredy, Atomics International

B. Higgins, Eagle-Picher Industries, Joplin

R. Hudson, Eagle-Picher Industries, Joplin

J. R. Huff, U. S. Army Mobility Equipment R\&D Center, Fort Belvoir

R. A. Huggins, Stanford U.

R. A. Huse, Public Service Electric \& Gas Co., Newark, N. J.

S. D. James, U. S. Naval Surface Weapons Center, Silver Spring, Md.

M. A. Jansen, Allegheny Power Service Corp., Greensburgh, Pa.

G. Janz, Rensselaer Polytechnic Inst.

H. Jensen, C\&D Batteries, Plymouth Meeting, Pa.

F. Kalhammer, Electric Power Research Institute

C. Kamienski, Lithium Corp. of America, Gastonia, N. C.

M. Xatz, Div. Energy Storage Systems, USDOE

K. Kinsman, Ford Motor Co., Dearborn, Mich.

R. Kirk, Div. of Electric and Hybrid Vehicle Systems, USDOE

K. W. Klunder, Div. of Energy Storage Systems, USDOE

J. Kollar, Northfield, Ill.

J. Lagowski, Detroit Edison Utility Co.

H. Laitinen, U. Florida

J. J. Lander, Air Force Aero Propulsion Lab., Wright-Patterson AFB

A. Landgrebe, Div. of Energy Storage Systems, USDOE (6)

C. E. Larson, Bethesda, Md.

S. H. Law, Northeast Utilities, Hartford, Conn.

C. A. Levine, Dow Chemical Co., Walnut Creek, Calif.

D. Linden, U. S. Army Electronics Command, Fort Monmouth, N. J.

R. Llewellyn, Indiana State U.

P. S. Lykoudis, Purdue Univ.

J. Mathers, U. Maryland

C. J. Mazac, PPG Industries, Corpus Christi

J. McKeown, Office of Resource Management, USDOE

F. McLarnon, Lawrence Berkeley Lab.

C. McMurty, Carborundum Co., Niagara Falls

D. Meighan, C\&D Batteries, Plymouth Meeting, Pa.

R. C. Miller, Kawecki Berylco Industries, Inc., Boyertown, Pa.

R. Minck, Ford Motor Co., Dearborn, Mich.

R. Murie, General Motors Corp., Warren, Mich.

E. M. Murman, Flow Research Co., Kent, Wash.

G. Murray, Detroit Edison Utility Co.

J. Newman, U. California, Berkeley

J. Nowabilski, Union Carbide Co., Tonawanda

C. Pax, Div. Electric and Hybrid Vehicle Systems, USDOE (6)

G. F. Pezdirtz, Div. of Energy Storage Systems, USDOE

R. Pollard, U. California, Berkeley

R. K. Quinn, Sandia Labs.

L. H. Raper, Eureka Co., Bloomington, Ill.

R. Rightmire, Standard Oil of Ohio, Cleveland

P. F. Ritterman, TRW Inc., Redondo Beach

R. Rizzo, Globe-Union, Inc., Milwaukee

N. Rosenberg, Transportation Systems Center, Cambridge, Mass.

P. N. Ross, Lawrence Berkeley Lab.

R. Rubischko, Chloride Inc., Tampa

A. J. Salkind, Rutgers U.

A. F. Sammells, Inst. Gas Technology, Chicago

W. Schaefer, Commonwealth Edison, Maywood, Ill.

G. Scharbach, American Motors General Corp., Wayne, Mich. 
T. Schneider, Public Service Electric \& Gas Co., Newark, N. J.

R. I. Schoen, National Science Foundation

J. R. Schorr, Battelle Memorial Inst., Columbus

D. R. Schramm, Public Service Electric \& Gas Co., Newark, N. J.

H. J. Schwartz, NASA Lewis Research Center

J. R. Selman, Illinois Inst. Technology

J. A. Shrupshire, Exxon Research and Engineering Co., Linden, N. J.

R. Singleton, U. S. Bureau of Mines, Washington

A. I. Snow, Atlantic Richfield Co., Harvey, Ill.

S. Srinivasan, Brookhaven National Lab.

D. Stakem, Catalyst Research Corp., Baltimore

E. Steeve, Commonwealth Edison Co., Chicago

R. H. Strange II, National Science Foundation

R. L. Strombotne, U. S. Dept. Transportation, Washington

S. Sudar, Atomics International

R. H. Swoyer, Pennsylvania Power and Light Co., Allentown

P. C. Symons, Energy Development Assoc., Madison Heights, Mich.

R. Szwarc, General Electric Co., St. Petersburg

F. Tepper, Catalyst Research Corp., Baltimore

L. Thaller, NASA Lewis Research Center

G. M. Thur, Div. Highway Systems, USDOE

C. W. Tobias, U. California, Berkeley

L. Topper, Div. of Res. \& Technical Assessment, USDOE

W. Towle, Globe-Union, Inc., Milwaukee

A. A. Uchiyama, Jet Propulsion Lab.

J. Vanderryn, Office of International Affairs, USDOE

J. V. Vinciguerra, Eagle-Picher Industries, Joplin

J. B. Wagner, Arizona State U.

R. D. Walker, Jr., U. Florida

C. O. Wanvig, Jr., Globe-Union, Inc., Milwaukee

S. A. Weiner, Ford Motor Co., Dearborn, Mich.

J. Werth, ESB Inc., Yardley, Pa.

C. Wienlein, Globe-Union, Inc., Milwaukee

Z. Will, General Electric R\&D Center, Schenectady

A. Williams, Dow Chemical Co., Midland, Mich.

J. Withrow, Chrysler Corp., Detroit

S. E. Wood, El Paso, Tex.

T. Wydeven, NASA Ames Research Center

L. S. Yao, U. Illinois

O. Zimmerman, Portland General Electric Co., Portland, Ore.

M. Zlotnick, Energy Technology, USDOE

Chloride Technical Limited, Manchester, England

L. Pearce, Admiralty Materials Lab., Holten Heath, England

E. Voss, Varta Batterie A. G., Kelkhern, Germany

E. Aiello, U. Chicago

W. J. Argersinger, Jr., U. Kansas

K. J. Bell, Oklahoma State U.

R. Blanco, Oak Ridge National Lab.

C. F. Bonilla, Columbia U.

W. Brandt, U. Wisconsin, Milwaukee

A. E. Dukler, U. Houston

W. J. Frea, Michigan Technological U.

J. E. Linehan, Marquette U.

Maine Univ., Prof. in charge of Chem. Engr. Lib. 
Marquette U., Dept. of Chemistry

Michigan Technological U., Library

N. R. Miller, United Nuclear Industries, Richland

G. Murphy, lowa State U.

E. A. Peretti, U. Notre Dame

G. W. Preckshot, U. Missouri

H. Rosson, U. Kansas

C. Sanathanan, U. Illinois-Chicago Circle

A. Sesonske, Purdue U.

USDOE, Director, Office of Safeguards and Security

B. W. Wilkinson, Michigan State U.

Comision Nacional de Energia Atomica, Library, Argentina

J. A. Sabato, Com. Nac. de Energia Atomica, Buenos Aires, Argentina

C. H. Cheng, National Tsing Hua Univ., China

National Radiological Protection Board, Library, Harwell, England

L. Kemmerich, Ges. fur Kernforschung, Karlsruhe, Germany

F. Weigel, Inst. fur Anorganische Chemie der U. Munich, Germany

N. Saratchandran, Bhabha Atomic Research Centre, Bombay, India

K. Fujimiya, U. of Tokyo, Japan

Japan Atomic Energy Research Inst., Tokai-mura, Japan

K. Matsuda, Inst. of Physical \& Chemical Res., Yamato-machi, Japan

S-S. Lee, Korea Advanced Institute of Science, Korea

Korean Atomic Energy Research Institute, Korea

R. Nordberg, Sahlgren's Hospital, Göteborg, Sweden

T. Wallin, Royal Inst. Technology, Stockholm 